\title{
Allium stenodon (= A. baekdusanense), a neglected member among the Korean flora
}

\author{
Young Moon KIM, Jungsim LEE ${ }^{1}$ and Hyeok Jae CHOI* \\ Department of Biology and Microbiology, Changwon National University, Changwon 51140, Korea \\ ${ }^{1}$ Division of Forest Biodiversity and Herbarium, Korea National Arboretum, Pocheon 11186, Korea
}

(Received 22 April 2021; Revised 11 May 2021; Accepted 26 May 2021)

\begin{abstract}
Allium stenodon (Amaryllidaceae) is reported as a returning member of the Korean flora. This species proved to be the only member of the section Sikkimensia among Korean Allium species, and it is easily distinguished by its cylindrical bulbs with fibrous to sometimes subreticulate tunics and blue to purple-blue perianth. Previously recognized $A$. baekdusanense is treated as an additional synonym of $A$. stenodon. Photographs and complete descriptions of $A$. stenodon are provided together with a dichotomous key to the Korean Allium species. In addition A. stenodon is newly recorded in Jilin province in China.
\end{abstract}

Keywords: Amaryllidaceae, Allium stenodon, A. baekdusanense, section Sikkimensia, Korea

The genus Allium L. (Amaryllidaceae) is one of the largest genera of monocots (Sinitsyna et al., 2016). Recently, the number of species within the genus is estimated at 920 (Seregin et al., 2015). In Korea, 20 species are recognized, of which five species are endemic to the country (Choi and Oh, 2011; Choi et al., 2019; Korea National Arboretum, 2020; Jang et al., 2021).

Allium stenodon Nakai \& Kitag. was firstly described by Nakai and Kitagawa (1934) with the type material from Wuling-shan Mt. of Hebei province, China. This species belongs to section Sikkimensia (Traub) N. Friesen, which is subordinated to subgenus Reticulatobulbosa (Kamelin) N. Friesen (Li et al., 2010). This section is usually characterized by cylindric bulbs, fibrous and subreticulate bulb tunics, and mostly blue to purple (rarely white) perianth (Xu and Kamelin, 2000; Friesen et al., 2006). The species of section Sikkimensia occurs mainly in southwestern and southern China (Friesen et al., 2006). Currently A. stenodon is considered as an endemic species of China, and it is known to occur in Hebei, Henan, Nei Mongol, and Shanxi provinces (Xu and Kamelin, 2000). This species prefers forest margins, slopes, and pastures of 1,600-3,000 m a.s.l. (Xu and Kamelin, 2000).

In Korea, A. stenodon was firstly recorded by Kitagawa
(1939). Since then, this species had been enumerated in the Korean flora by Park (1949) and Kitagawa (1954, 1965, 1979). Especially, Kitagawa (1954) presented the voucher specimens collected from Kwanmobong Mt. and Buksubaeksan Mt. in Korea. However, Yu et al. (1981) treated A. stenodon as a synonym A. cyaneum Regel (section Sikkimensia), and it led to a taxonomic problem because A. cyaneum is not found in Korea (Xu and Kamelin, 2000; Choi and Oh, 2011). Choi and Oh (2011) also misrecognized this species as a synonym of $A$. thunbergii var. thunbergii (section Sacculiferum P. P. Gritzenko). Due to these taxonomic errors and inadequate material seen in the field or in herbaria, the noteworthy record of $A$. stenodon in Korea has been neglected in the recent Korean floras such as Oh and Choi (2018) and Korea National Arboretum (2020).

During research on the taxonomic identity of little known A. baekdusanense Y. N. Lee (Lee, 2005), we have concluded that $A$. baekdusanense is an additional synonym of $A$. stenodon. In addition, we found herbarium materials of $A$. stenodon from Korea and its neighboring Jilin province, China in the herbaria of TI and PE (abbreviations are according to Thiers, 2020), respectively. Therefore, the goal of this study is to report A. stenodon as a returned member

\footnotetext{
*Author for correspondence: hjchoi1975@changwon.ac.kr
} 
of the Korean flora with a taxonomic treatment on $A$. baekdusanense. Photographs of A. stenodon are provided together with complete descriptions including information on the nomenclatural type, synonymy, distribution, and specimens examined. Furthermore, a key to the Allium species in Korea is provided.

\section{Taxonomic Treatment}

Allium stenodon Nakai \& Kitag., Rep. Exped. Manchoukuo sect. iv 1: 18, pl. 6, 1934; A. cyaneum var. stenodon (Nakai \& Kitag.) Kitag., Rep. Inst. Sci. Res. Manchoukou 6: 120, 1942; A. cyaneum f. stenodon (Nakai \& Kitag.) Kitag. J. Jap.

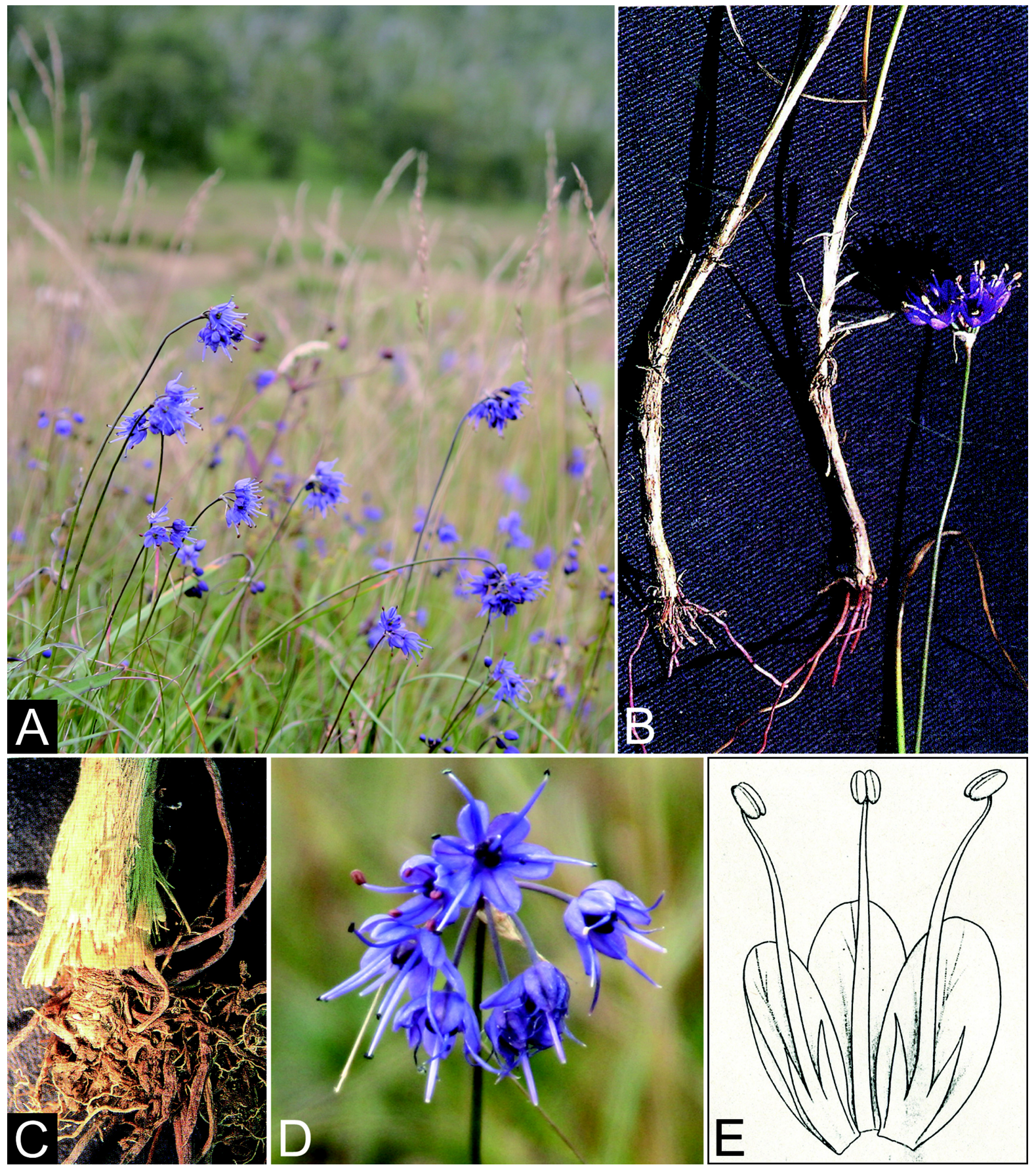

Fig. 1. Allium stenodon (= A. baekdusanense). A. Habit. B. Type material of A. baekdusanense (scanned from Lee, 2005). C. Bulb (scanned from Lee, 2005). D. Inflorescence with flowers. E. Tepal and filament arrangement (scanned from Nakai and Kitagawa, 1934). A and D, photos by Yong-Jin Kwon from Baekdusan Mt., China, 10 Jul 2005. 
Bot. 40: 138, 1965; A. plurifoliatum var. stenodon (Nakai \& Kitag.) J. M. Xu, Fl. Reipubl. Popularis Sin. 14: 233, 1980.TYPE: CHINA. Hebei: in sylvis montis Wu-ling-shan, 2 Sep 1933, T. Nakai, M. Honda \& M. Kitagawa s.n. (holotype, TI photo!) (Figs. 1, 2).

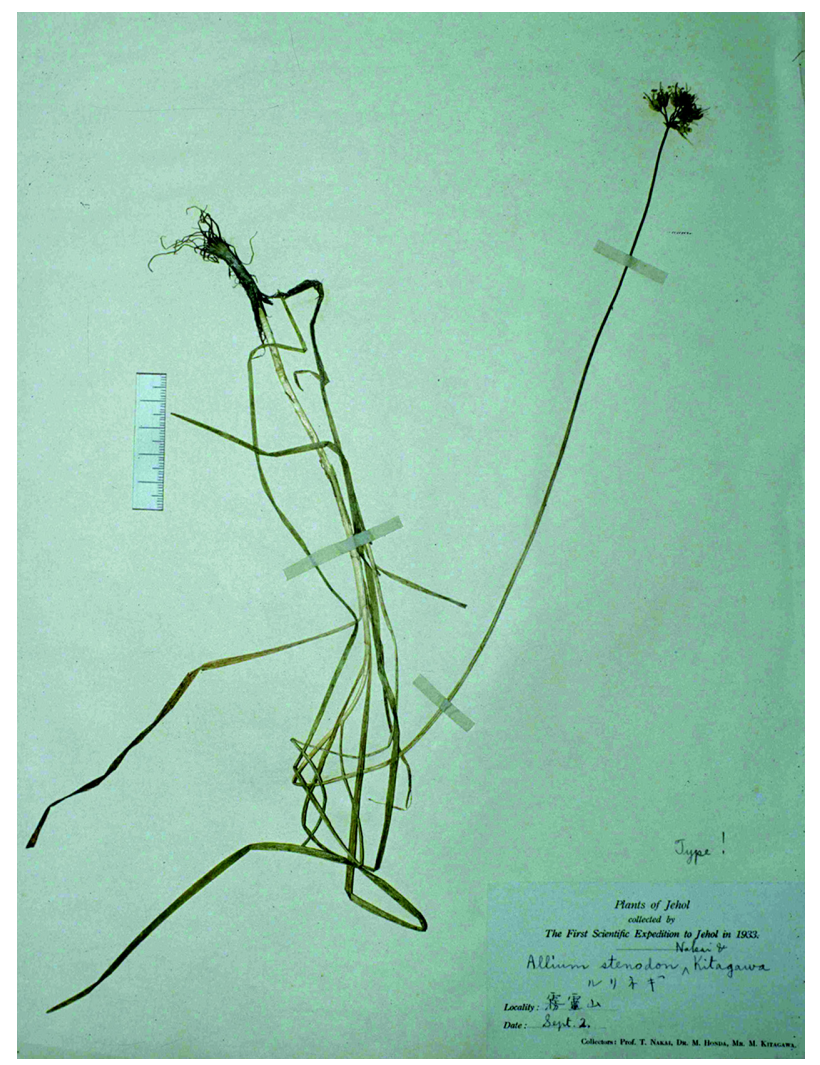

Fig. 2. Holotype of Allium stenodon.
Allium baekdusanense Y. N. Lee, Bull. Korea Pl. Res. 5: 28, 2005.-TYPE: Korea. Baekdusan Mt., 9 Sep 2005, Y. N. Lee \& Y. S. Kim s.n. (holotype, Korea Plant Research Institute).

Herbs hermaphroditic. Roots fibrous, dark brown. Rhizomes short and thick, ca. $5 \mathrm{~mm}$ long. Bulbs usually clustered, cylindric, slightly thickened at base, $3-8 \mathrm{~mm}$ in diam.; tunics fibrous, sometimes subreticulate, brown. Leaves usually 2 or 3; sheaths exposed above ground; blades linear, flat to semicircular in cross-section, shorter than to subequaling scape, 1-3 mm wide. Inflorescences umbellate, subfascicled to hemiglobose, 7-20 flowered; scapes terete, $10-30 \mathrm{~cm} \times 1-3 \mathrm{~mm}$; pedicels terete, subequal in length, 5$8 \mathrm{~mm}$ long; bracts white, membranous; beak short. Flowers: perianth semi-radially spreading, blue to purple-blue; outer tepals ovate, boat-shaped, $4.5-6.5 \times 2-3 \mathrm{~mm}$; inner tepals longer than outer ones, ovate-oblong, 5-7 × 2-3 mm; filaments exserted, subulate; inner filaments broadened and with 1 tooth on each side at base; anthers elliptical; ovary obovoid, greenish, with concave nectaries covered by hoodlike projections at base; style terete, exserted; stigma smooth. Fruit capsule, cordiform, trigonous. Seeds black, elliptical to oval.

Korean name: Buk-su-baek-san-pa (북수백산파) (Park, 1949).

Phenology: Flowering July to early September.

Distribution: China (Hebei, Henan, Nei Mongol, Shanxi, Jilin) and Korea (northern part: Yanggang-do, Hamgyeongbukdo, Hamgyeongnam-do) (Fig. 3).

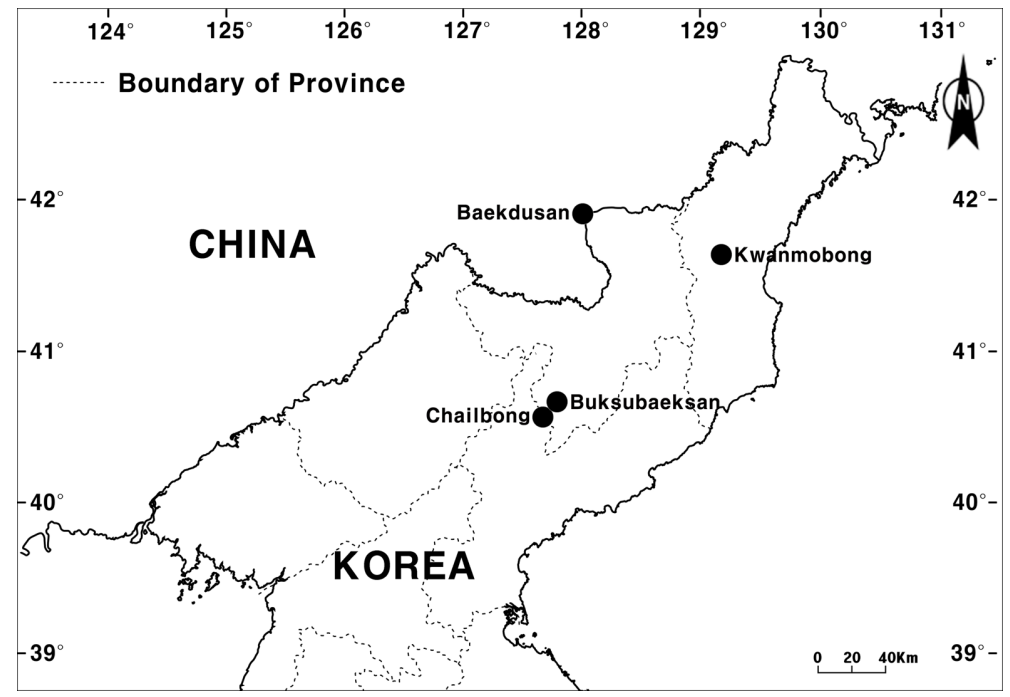

Fig. 3. Distribution map of Allium stenodon in Korea and neighboring China. Distribution points (black circles) are based on the specimens examined in this study and the voucher information from Kitagawa (1954). 
Specimens examined: CHINA. Hebei: Po-hua-shan, 4 Sep 1936 [fl], T. F. King 530 (PE); 6 Aug 1934 [fl], C. W. Wang 62109 (PE); Hsiao-wu-tai-shan, 1 Sep 1921 [fl], Harry Smith 354 (PE); Beijing, 2 Sep 1955 [fl], Yang 1754 (PE); 26 Jul 1933 [fl], C. W. Wang 60168 (PE). Nei Mongol: 16 Aug 1964 [fl], Wu 22 (PE). Shanxi: 13 Aug 1929 [fl], W. Y. Hsia 1541 (PE); 21 Aug 1930 [fl], P. Licent S. J. 9952 (PE). Jilin: Jangbaishan (Hongtoshan) Mt., 18 Aug 1986 [fl], PB860T4 (PE).

KOREA. Hamgyeongbuk-do: Kwanmobong Mt., 19 Jul 1918 [fl], T. Nakai s.n. (TI). Hamgyeongnam-do: Chailbong Mt., 17 Aug 1935 [fl], T. Nakai \& M. Kitagawa s.n. (TI); Chailbong Mt., 18 Aug 1935 [fl], T. Nakai s.n. (TI).
Notes: Allium stenodon is the only member of section Sikkimensia in Korean Allium species, and is easily distinguished by its cylindric bulbs (Fig. 1B) with fibrous and sometimes subreticulate bulb tunics (Fig. 1C) and blue to purple-blue perianth (Fig. 1A, B, D). Meanwhile, all taxonomic observations of $A$. baekdusanense are overlapping (included in) the variation of $A$. stenodon (Fig. 1), and we could not find any diagnostic character of $A$. baekdusanense in this study. Consequently we propose $A$. baekdusanense as an additional synonym of $A$. stenodon. In addition, this species is newly recorded in Jilin province, China.

\section{Key to the Allium species in Korea (revised from Choi and Oh, 2011)}

Notes: The records of $A$. longistylum Baker in Korea (Choi et al., 2003; Choi and Oh, 2011; Oh and Choi, 2018) are all the result of misidentification of herbarium materials (Huang et al., 2021), the identity of which is the reophytic type of Allium thunbergii G. Don. (H. J. Choi, pers. obs.). Therefore, we exclude A. longistylum from the Korean flora, and organize the Korean Allium species with 21 species in this study. In addition, the new Korean name 'Geuk-dong-san-ma-neul (극동산마늘)' is given for $A$. ochotense Prokh. based on the name of the region, far eastern Asia, where the species is distributed (Herden et al., 2016; Choi et al., 2019). Authorities of all the scientific names below were provided in Korea National Arboretum (2020) and Jang et al. (2021).

1. Herbs usually dioecious; rhizomes threadlike; bulb tunics herringbone patterned; leaf blades with 1 row of vascular bundles in cross-section; hyaline sheaths present; scapes slender; inflorescences 1-3 flowered; inner tepals narrower than outer ones; style trigonous; stigma 3-cleft; flowering late March to May

1. A. monanthum

1. Herbs hermaphroditic (monoecious); rhizomes non-threadlike; bulb tunics smooth to reticulate; leaf blades usually with 2 rows of vascular bundles in cross-section; hyaline sheaths absent; scapes not slender; inflorescences more than 4 flowered; inner tepals not narrower than outer ones; style terete; stigma smooth to capitate; flowering May to October.

2. Bulbs subglobose, with bulbels; inflorescences sometimes with bulbils

2. A. macrostemon

2. Bulbs cylindrical to ovoid, without bulbels; inflorescences without bulbils.

3. Leaf blades oblong to oval, pseudo-petiolate at base; pedicels angular; ovary obconical, with 1 ovule per locule.

4. Leaf blade oval, apex obtuse to subrounded; perianth white 3. A. ulleungense

4. Leaf blades oblong to elliptical, apex acute; perianth creamy white to pale yellow.

5. Leaf blades $2.5-6 \mathrm{~cm}$ wide; perianth pale yellow $(2 n=16)$

4. A. microdictyon

5. Leaf blades $5-10 \mathrm{~cm}$ wide; perianth creamy white $(2 n=32)$

5. A. ochotense

3. Leaf blades linear, sessile at base; pedicels terete; ovary ovoid, obovoid or ellipsoid, with 2 ovules per locule.

6. Ovary without hood-like appendages at base.

7. Bulb tunics fibrous, reticulate; perianth white; tepals mucronate at apex

6. A. tuberosum

7. Bulb tunics membraneous or papery, smooth; perianth pink to lilac; tepals obtuse to rounded at apex.

8. Rhizomes condensed, non-branched; bulb tunics papery; leaf blades angular to terete in cross-section; scapes erect before flowering.

9. Leaf blade minutely angular in cross-section; pedicels unequal

7. A. anisopodium

9. Leaf blade terete in cross-section; pedicels subequal

8. A. tenuissimum

8. Rhizomes clearly elongated, branched; bulb tunics membranous; leaf blades flat in cross-section; scapes drooping at the upper parts before flowering.

10. Leaf sheaths buried under ground; perianth campanulate; leaf blades leathery, lustrous, inner tepals ovate-elliptical; inner filaments subulate.

11. Leaf blades 5-10 $\mathrm{mm}$ wide; scapes clearly flattened-winged in cross-section 9. A. spirale

11. Leaf blades $1.5-4 \mathrm{~mm}$ wide; scapes rhomboid to subterete in cross-section 10. A. spurium 
10. Leaf sheaths exposed above ground; leaf blades fleshy, glaucous; perianth radially spreading, inner tepals elliptical; inner filaments narrowly triangurlar or broadened up to middle part.

12. Leaf blades $2.5-4.5 \mathrm{~mm}$ wide; scapes subterete in cross-section; filaments non-exserted; inner filaments broadened up to ca. $2 / 3$ in length; flowering May to July $(2 n=16)$

11. A. minus

12. Leaf blades $5-13 \mathrm{~mm}$ wide; scapes rhomboid in cross-section; filaments exserted; inner filaments narrowly triangular; flowering September to October $(2 n=32)$

12. A. dumebuchum

6. Ovary with hood-like appendages at base.

13. Bulb tunics fibrous, reticulate; inner filaments clearly 2-4-toothed.

14. Perianth blue to purple-blue

13. A. stenodon

14. Perianth pale pink to reddish lilac.

15. Perianth radially spreading, pale pink; filaments clearly exserted $(2 n=16)$

14. A. koreanum

15. Perianth campanulate, reddish lilac; filaments slightly exserted $(2 n=32)$

15. A. splendens

13. Bulb tunics papery or thinly leathery, smooth; inner filaments usually entire or rarely minutely 2-toothed.

16. Bulb tunics thinly leathery, reddish brown; perianth pale yellow; ovary ovoid

16. A. condensatum

16. Bulb tunics papery, brown; perianth reddish pink to purple; ovary obovoid or elliptical.

17. Scapes hollow in cross-section; perianth reddish pink; tepals equal, oblong-lanceolate, acute at apex; ovary ellipsoid; filaments non-exserted; capsules ellipsoid; seed elliptical, angular in cross-section; flowering July to August

17. A. maximowiczii

17. Scapes solid in cross-section; perianth purple; tepals unequal, elliptical to oval, obtuse to rounded at apex; ovary obovoid; filaments exserted; capsules cordiform; seed oval, flat in cross-section; flowering September to October.

18. Perianth semi-radially spreading

18. A. taquetii

18. Perianth campanulate.

19. Leaf blades spreading, terete in cross-section, $19-80.5 \mathrm{~cm}$ long, tinged red at base

19. A. linearifolium

19. Leaf blades ascending to curved, flat, angular or terete in cross-section, $10-50 \mathrm{~cm}$ long, pale green at base.

20. Leaf blades leathery, lustrous, clearly flat in cross-section; scapes usually lateral from bulbs ....

20. A. pseudojaponicum

20. Leaf blades thinly leathery to papery, non-lustrous, flat, angular or terete in cross-section; scapes terminal from bulbs

21. A. thunbergii

ORCID: Young Moon KIM https://orcid.org/0000-0002-5325-

603X; Jungsim LEE https://orcid.org/0000-0003-2815-6464;

Hyeok Jae CHOI https://orcid.org/0000-0001-6315-0071

\section{Acknowledgments}

This research was supported by the Changwon National University in 2021-2022.

\section{Conflict of Interest}

The authors declare that there are no conflicts of interest.

\section{Literature Cited}

Choi, H. J. and B. U. Oh. 2011. A partial revision of Allium (Ama- ryllidaceae) in Korea and north-eastern China. Botanical Journal of the Linnean Society 167: 153-211.

Choi, H.-J., B.-U. Oh and C.-G. Jang, 2003. An unrecorded species of Allium (Alliaceae) in Korea: A. longistylum Baker. Korean Journal of Plant Taxonomy 33: 295-301.

Choi, H.-J., S. Yang, J.-C. Yang and N. Friesen. 2019. Allium ulleungense (Amaryllidaceae), a new species endemic to Ulleungdo Island, Korea. Korean Journal of Plant Taxonomy 49: 294-299.

Friesen, N., R. M. Fritsch and F. R. Blattner. 2006. Phylogeny and new intrageneric classification of Allium (Alliaceae) based on nuclear ribosomal DNA ITS sequences. Aliso 22: 372-395.

Herden, T., P. Hanelt and N. Friesen. 2016. Phylogeny of Allium L. subgenus Anguinum (G. Don. ex W. D. J. Koch) N. Friesen (Amaryllidaceae). Molecular Phylogenetics and Evolution 95: 79-93. 
Huang, D.-Q., A.-G. Zhen and X.-X. Zhu. 2021. Allium yingshanense, a new species from the Dabie Mountains (east-central China), and taxonomic remarks on the related species. Phytotaxa 498: 227-241.

Jang, J. E., J.-S. Park, J.-Y. Jung, D.-K. Kim, S. Yang and H. J. Choi. 2021. Notes on Allium section Rhizirideum (Amaryllidaceae) in South Korea and northeastern China: with a new species from Ulleungdo Island. PhytoKeys 176: 1-19.

Kitagawa, M. 1939. Lineamenta Florae Manshuriaceae. Report of the Institute of Scientific Research, Manchoukuo 3 Append 1: $1-488$.

Kitagawa, M. 1954. Notulae fractae ob floram Asiae orientalis (8). Journal of Japanese Botany 29: 4-11. (in Latin and Japanese)

Kitagawa, M. 1965. Notulae fractae ob floram Asiae orientalis (20). Journal of Japanese Botany 40: 6-11. (in Latin and Japanese)

Kitagawa, M. 1979. Neo-Lineanmenta Florae Manshuricae. Staues \& Cvamer Gmbh, Hirschberg, 715 pp.

Korea National Arboretum. 2020. Checklist of Vascular Plants in Korea (Native Plants). Korea National Arboretum, Pocheon, 1006 pp. (in Korean).

Lee, Y. N. 2005. A new species of Allium. Bulletin of Korea Plant Research 5: 28-29.

Li, Q.-Q., S.-D. Zhou, X.-J. He, Y. Yu, Y.-C. Zhang and X.-Q. Wei. 2010. Phylogeny and biogeography of Allium (Amaryllidaceae: Allieae) based on nuclear ribosomal internal transcribed spacer and chloroplast rps 16 sequences, focusing on the inclusion of species endemic to China. Annals of Botany 106: 709-733.

Nakai, T. and M. Kitagawa. 1934. New herbaceous plants of Jehol which were collected along the way from Chéng-té to Hsinglung, in Wu-ling-shan Mts., and at Chang-shan-yü. Report of the First Scientific Expedition to Manchoukuo IV; Plnatae Novae Jeholenses 1: 14-70.

Oh, B. U. and H. J. Choi. 2018. Allium L. In The Genera of Vascular Plants of Korea. Park, C.-W. (ed.), Hongreung Publishing Co., Seoul. Pp. 1700-1709.

Park, M. K. 1949. An Enumeration of Korean Plants. Ministry of Education, Government of the Republic of Korea, Seoul, 176 pp. (in Korean).

Seregin, A. P., G. Anačkov and N. Friesen. 2015. Molecular and morphological revision of the Allium saxatile group (Amaryllidaceae): geographical isolation as the driving force of underestimated speciation. Botanical Journal of the Linnean Society 178: $67-101$.

Sinitsyna, T. A., T. Herden and N. Friesen. 2016. Dated phylogeny and biogeography of the Eurasian Allium section Rhizirideum (Amaryllidaceae). Plant Systematics and Evolution 302: 1311-1328.

Thiers, B. 2020 [continuously updated]. Index Herbariorum: a global directory of public herbaria and associated staff. New York Botanical Garden's Virtual Herbarium. Retrieved Nov. 5, 2011, available from http://sweetgum.nybg.org/ih/.

Xu, J.-M. and R. V. Kamelin. 2000. Allium L. In Flora of China, Vol. 24. Flagellariaceae through Marantaceae. Wu, Z. Y. and P. H. Raven (eds.), Science Press, Beijing and Missouri Botanical Garden Press, St. Louis, MO. Pp. 165-202.

Yu, S. O., S. Lee and W. T. Lee. 1981. A taxonomic study on the Allium species in Korea. Journal of Korean Plant Taxonomy 11: 21-41. (in Korean) 